\title{
Design optimization of a building attached sunspace through experimental monitoring and dynamic modelling
}

\author{
Martina Guasco ${ }^{1}$, Martina Orlanno ${ }^{1}$, Chiara Piccardo $^{2}$, Andrea Giachetta ${ }^{1}$, Ambrose Dodoo ${ }^{2 *}$ \\ ${ }^{1}$ Department of Architecture and Design, University of Genoa, 16123 Genoa, Italy \\ ${ }^{2}$ Faculty of Technology, Linnaeus University, SE-35195 Växjö, Sweden
}

\begin{abstract}
In Europe, buildings are responsible for $40 \%$ of the energy consumption and $36 \%$ of the $\mathrm{CO}_{2}$ emissions. Space heating largely contributes to these energy and climate impacts. Passive solar heating systems, as sunspaces, can contribute to increase solar heat gains, reducing space heating energy demand and the related use of fossil fuels. Careful design and local climatic considerations are essential to optimize the performance of sunspaces. In this study experimental field monitoring, dynamic modelling and steadystate methods are applied to analyse the thermal behaviour of an attached sunspace in an Italian existing building, as well as its potential contribution to the building's energy balance. Design modifications for improved thermal performance of the sunspace are investigated. The results show overall agreement between the dynamic modellings and experimental monitoring of the sunspace and indicate that the sunspace's indoor air temperature and hence solar energy gains are significantly increased with the design modifications, in contrast to the existing configuration. Maximum temperatures between 44 and $48{ }^{\circ} \mathrm{C}$ were observed for the existing and a modified alternative of the analysed sunspace. The dynamic simulation model and design modifications presented in this study can serve as basis for assessment and optimal configurations of sunspaces in their design stage.
\end{abstract}

\section{Introduction}

There is growing emphasis on shifting from fossil to renewable fuels in the ongoing efforts to mitigate climate change [1]. Fossil fuels currently represent $78 \%$ and $81 \%$ of the total primary energy use in the European Union (EU) [2] and worldwide [3], respectively. Fossil fuel combustion is a key source of anthropogenic greenhouse gas (GHG) emission, warming and destabilizing the earth's climate system [4]. The Paris agreement emphasized the need for climate change mitigation strategies to keep the increase in global average surface temperature to well below $2^{\circ} \mathrm{C}$ above pre-industrial levels [5]. The Italian national energy strategy [6], aims to reduce the share of fossil fuels in the total national primary energy from $86 \%$ in 2010 to $76 \%$ by 2020 . Further the Italian strategy includes increasing the share of renewable resources in the energy mix to $28 \%$ by 2030 and reducing total primary energy use and $\mathrm{CO}_{2}$ emission by $24 \%$ and $34 \%$ by 2030 , respectively, compared with baseline of 2010 [7].

The EU's Energy Performance of Buildings Directive calls for member states to implement policies for improved energy efficiency in buildings, and increased deployment of nearly zero energy buildings (nZEB) which are characterised by low energy demand and energy supply from renewable sources [8]. The building sector is noted to be crucial in achieving the Italian government's energy- and climate-related targets
$[6,9]$. The residential sector is responsible for $28 \%$ of Italy's total final energy consumption [9]. Space heating is the dominant energy end-use in most EU countries and together with air conditioning accounted for about $70 \%$ of the final energy use in the Italian residential sector in $2016[9,10]$. The Italian nZEB definition emphasizes onsite energy production from renewable energy sources (RES) in new and retrofitted buildings [11]. The InterMinisterial Decree 26 June 2015 [12], based on the Legislative Decree no. 28/2011, sets a minimum share of energy from RES of $50 \%$ for only tap water heating, and $50 \%$ for tap water heating, space heating and space cooling, as a whole, from 2018. Although the decree does not indicate the use of specific RES systems, this stipulation enhances the application of solar thermal heating and photovoltaic systems, which are already widely implemented and used in Italy [13].

\subsection{State of the art}

There has been growing interest in passive solar strategies to reduce the energy use of buildings in recent years. Passive solar heating systems are designed to optimize the use of sunlight for space conditioning of buildings during winter seasons. This can improve the energy efficiency, reduce the use of fossil fuels and increase the use of a renewable energy source in buildings, particularly in climatic zones with adequate solar radiation during the winter season [14]. Passive

\footnotetext{
* Corresponding author: ambrose.dodoo $@$ Inu.se
} 
solar heating can typically meet $20-30 \%$ of the seasonal heating demand of buildings in European climate [15]. Sunspaces may be attached or integrated in buildings as passive solar heating system to harness, store and redistribute solar energy in buildings, especially in areas with abundant high-intensity solar radiation and lowinsulated buildings as Southern Europe [16, 17].

The EN ISO 13789 [18] and 13790 [19] propose simplified methodology to calculate the heat transfer between conditioned and unconditioned (sunspaces) zones under steady-state conditions. Asdrubali et al. [20] compared results based on EN ISO 13790 methodology and dynamic simulation, respectively, finding that the contribution of the attached sunspace is underestimated by the steady-state methodology but the expected heating demand of the apartment is consistent. Panão et al. [21] and Buonomano et al. [22] showed that the EN ISO 13790 methodology underestimates the thermal performance of sunspaces and other passive solar devices, especially in mid and cold seasons, because of the approximate computation of indirect gains. RuizPardo et al. [23], applying the same calculation method to Trombe walls, showed that the proposed methodology is conservative for solar gains, since it does not take into account the actual thermal resistance of passive solar devices. Hence this method may be less effective, particularly in the Mediterranean climate.

Careful design and local climatic considerations, as well as building operational configurations, are essential to optimize the thermal performance of sunspaces [24, 25]. Dynamic simulation is essential to accurately design sunspaces, due to the complex interaction of factors influencing the thermal performance of such systems. Field monitoring can play an important role in accurately characterizing the performance of sunspaces and validating calculations of simulation software.

Some studies have investigated thermal performance of passive solar design strategies for buildings in various climatic contexts. Stevanović [26] performed a detailed review of simulation-based optimization studies of passive solar design strategies for buildings, including sunspaces. Strategies and tools to implement energyefficient and cost-effective passive solar heating systems were explored in the OFFICE European research project [27]. A number of studies [e.g., 17, 24, 28, 29] compared different configurations of passive solar devices based on dynamic modelling, exploring the influence of design parameters on the thermal performance of the devices.

Literature also shows experimental studies of passive solar heating systems in different climatic conditions and building typologies. Chandel and Aggarwal [30] monitored the indoor temperature in an office building with attached sunspace in a high-altitude region of North India. The authors found that the solar heat gain based on monitored data is greater than that estimated with a standard steady-state method. Chen and Shi [31] analysed the indoor air temperature of rural residential buildings with attached sunspaces in China. Krüger and Givoni [32] carried out a long-term temperature monitoring of a residential building with passive solar devices situated in Israel, developing an indoor temperature prediction formula. Zhu and Chen [33] did the same with a residential building with attached Trombe walls situated in North-East China. Rempel et al. [34] measured the indoor air and surface temperature of four dwellings with attached sunspaces in Oregon and used the measurement to validate simulation modells. With the same purpose, Mottard and Fissore [35], Sánchez-Ostiz, et al. [36], Owrak et al. [37] and Ulpiani et al. [38] measured the indoor temperatures of experimental rooms with attached sunspace in Concepción (Chile), Pamplona (Spain), Karaj (Iran) and Perugia (Italy), respectively. These studies generally show that performances of passive solar heating systems, as sunspaces, strongly depend on the specific weather or climate context as well as on operative conditions. Notwithstanding, much of the literature on performance of sunspaces is based on simulation studies and a few field monitoring studies. Very few studies have integrated field monitoring and detailed simulation to comprehensively characterize and analyse strategies to improve dynamic thermal behaviours of sunspaces.

The mentioned Refs [17, 24, 28, 34, 36, 37, 38] and Monge-Barrio and Sánchez-Ostiz [39] focused on design optimization of sunspaces based on thermal comfort and energy saving criteria. They concentrate on the winter operation of sunspaces as passive solar heating systems, with the exception of Monge-Barrio and Sánchez-Ostiz [39], who explored the summer overheating risk of sunspaces in different locations in Spain. These studies compared different configurations of sunspaces, changing design parameters as orientation, glazed-toopaque surface area ratio, number of glass panes, glass properties, thermal mass of the partition wall and ventilation rate. Bataineh and Fayez [24] compared the thermal performance of a sunspace with North, South and East orientation, alternatively, finding that the South-oriented sunspace has a solar heat gain up to about $35 \%$ and $70 \%$ higher than the East- and North-oriented sunspaces, respectively. Oliveti et al. [28] observed the same trend for the indoor air temperature of a sunspace with alternative South and East orientations. Rempel et al. [34] highlighted that orientation has a minor effect on the thermal performance of sunspace compared to other factors, as shadings. However, studies usually assume South as the standard orientation of passive solar devices in the northern hemisphere. The Refs [24, 38] showed that the solar heat gain can increase by increasing the ratio between the glazed and opaque surface area of the attached sunspace. However, Ulpiani et al. [38] highlighted that extending the glazed surface to the roofing floor can be counterproductive, because it increases the winter heat losses without efficiently increasing the solar heat gain, especially in case of a horizontal surface. Chiesa et al. [17] found that the number of glass panes can affect the thermal performance of the sunspace depending on the level of insulation of the building. The authors showed that the number of glass panes does not significantly affect the solar heat gain in uninsulated buildings but can significantly affect it in well-insulated buildings. Bataineh and Fayez [24] showed that single glazed surfaces generally perform better than double ones. Lowe coatings in double glazed surfaces can increase the 
solar heat gain of the sunspace compared to single glazed surfaces [17, 38]. However, single glazed surfaces remain the most cost-effective glazing solution [17]. Increasing the thermal mass of partition walls can give a steadier temperature inside the room heated by the sunspace [36, 37] and, consequently, energy savings throughout the heating period [37]. For the same reason, substituting opaque partition walls with glazed surfaces may not be profitable in terms of temperature stability [36] and energy savings [38]. Oliveti et al. [28] compared light and heavy partition walls with internal heat capacity of $173.5 \mathrm{~kJ} / \mathrm{m}^{2} \mathrm{~K}$ and $302.1 \mathrm{~kJ} / \mathrm{m}^{2} \mathrm{~K}$, respectively, finding that heat gains for the adjacent rooms do not differ significantly, as they increase by $0.5 \%$ and $1.3 \%$, respectively, by increasing the absorption coefficient of the wall surface from 0.2 to 0.5 . Finally, mechanical ventilation systems optimize the solar heat gain conveyed from the sunspace to the adjacent room, with positive effect on indoor air temperature [28] and energy savings [38].

Literature shows the importance of dynamic modelling for optimization of sunspaces, as their thermal performance is highly sensitive to local climate factors and design choices. In this study, we explore the thermal behaviour of an attached sunspace under dynamic operation conditions and propose design modifications to improve the thermal performance of the sunspace. We analyse the contribution of the sunspace to the energy balance and space heating need of an adjacent apartment.

\section{Methodology}

We use experimental monitoring and dynamic hour-byhour simulation to characterize and analyse the thermal behaviour of a building attached sunspace. Our approach encompasses: (i) monitoring of indoor air temperatures in the sunspace and adjacent room of an apartment in a studied building; (ii) dynamic modelling of the thermal behaviour of the sunspace; (iii) evaluation of design modifications for improved performance of the sunspace as passive solar heating system; and (iv) calculation of the heat gains from the sunspace.

\subsection{Studied location and building}

We studied a five-storey multi-family building in Savona (latitude 44.30, longitude 8.46), a municipality in northern Italy. Savona's climate is a Mediterranean temperate climate (Csa) according to Köppen-Geiger's climate classification, characterised by mild winters and hot summers, and precipitations mainly occurring in winter. Savona's average annual outdoor air temperature is about $16.5{ }^{\circ} \mathrm{C}$ whiles its maximum mean monthly outdoor air temperature is about $37.3{ }^{\circ} \mathrm{C}$, in August, and minimum mean monthly outdoor air temperature is about $-4{ }^{\circ} \mathrm{C}$, in January, between 2009 and 2018 [40].

The building consists of 20 apartments with a total heated floor area of $1000 \mathrm{~m}^{2}$. The building is part of a residential building complex (Figure 1) built in the late 1950's, and co-owned by ARTE Savona, the Regional Housing Department in Savona.

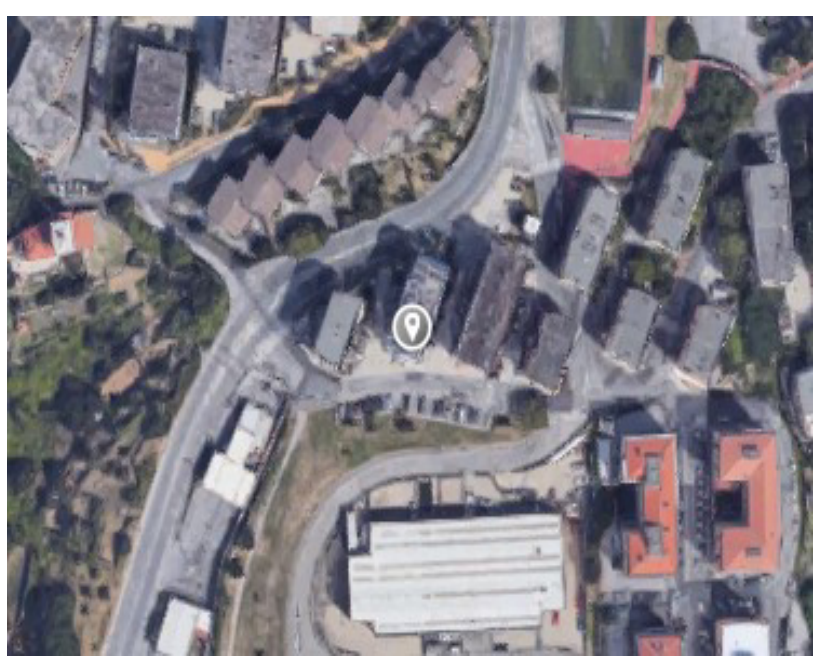

Fig. 1. Aerial view of the area with the case study marked.

The building has a reinforced concrete-frame structure infilled with double-layer brick walls. In 2003, the building underwent major renovations, including thermal improvement of the envelope and installation of sunspaces on the existing South façade. Table 1 shows the current construction and thermal characteristics of the studied building.

Table 1. Characteristics of the studied building.

\begin{tabular}{llc}
\hline Building part & Description & $\begin{array}{c}\text { U-value } \\
{\left[\mathbf{W} / \mathbf{m}^{2} \mathbf{K}\right]}\end{array}$ \\
\hline Attic floor & $\begin{array}{l}\text { 200 mm concrete }+40 / 80 \mathrm{~mm} \\
\text { cement levelling screed }+80 \mathrm{~mm} \\
\text { glass foam }\end{array}$ & 0,32 \\
Basement walls & $\begin{array}{l}20 \mathrm{~mm} \text { cement plaster }+80 \mathrm{~mm} \\
\text { brick }+180 \mathrm{~mm} \text { air gap }+60 \mathrm{~mm}\end{array}$ & 0,51 \\
& $\begin{array}{l}\text { brick }+15 \mathrm{~mm} \text { gypsum plaster } \\
\text { External walls }\end{array}$ & $\begin{array}{l}20 \mathrm{~mm} \text { cement plaster }+50 \mathrm{~mm} \\
\text { cork }+20 \mathrm{~mm} \text { cement plaster }+80\end{array}$ \\
& $\begin{array}{l}\text { mm brick }+180 \text { mm cellulose gap } \\
\text { filling }+60 \mathrm{~mm} \text { brick }+15 \mathrm{~mm}\end{array}$ \\
& $\begin{array}{l}\text { gypsum plaster } \\
20 \mathrm{~cm} \text { cement plaster }+150 \mathrm{~mm} \\
\text { concrete }+30 \text { mm cement screed }+\end{array}$ & 3.03 \\
$\begin{array}{l}\text { Intermediate } \\
\text { floor slabs }\end{array}$ & $\begin{array}{l}\text { 20 mm floor boarding } \\
\text { Windows }\end{array}$ & Single-glazed windows \\
\hline
\end{tabular}

\subsubsection{Building attached sunspaces}

The four sunspaces on the South façade consist of a freestanding steel-framed structure filled with clear glass panes (Figure 2). The glazed part is equipped with windows and external rolling blinds. Four new French doors were opened on the South façade to connect the sunspaces with the adjacent apartments. The partition wall between the sunspace and the adjacent room has the same construction characteristics of the external walls but it lacks the external insulation layer. It is equipped with two operable air vents, each dimensioned 200x200 $\mathrm{mm}$, on the top and the bottom, respectively, with a net distance of $2 \mathrm{~m}$. 


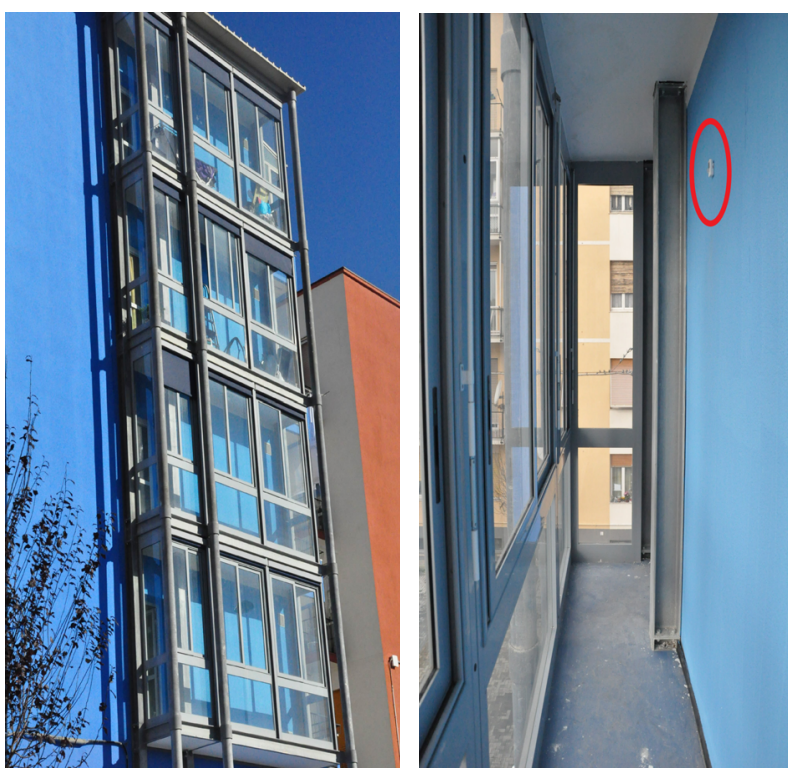

Fig. 2. On the left, general view of the sunspaces on the South façade of the studied building; on the right, internal view of the studied sunspace with the recording thermometer marked.

\subsubsection{Studied apartment and sunspace}

The studied apartment is a $50 \mathrm{~m}^{2}$ apartment on the third floor of the studied building with a South-facing attached sunspace. The sunspace is a non-habitable technical room with an area of $5 \mathrm{~m}^{2}$ and a volume of $15 \mathrm{~m}^{3}$. The sunspace is separated from the apartment with a French door, and from the above and below sunspaces with thermally insulated floor slabs (see also Table 2).

Table 2. Characteristics of the studied sunspace.

\begin{tabular}{|c|c|c|c|c|}
\hline $\begin{array}{l}\text { Sunspace } \\
\text { part }\end{array}$ & Description & $\begin{array}{l}\text { Area } \\
{\left[\mathbf{m}^{2}\right]}\end{array}$ & $\begin{array}{c}\text { U-value } \\
{\left[\mathbf{W} / \mathbf{m}^{2} \mathbf{K}\right.} \\
]\end{array}$ & $\begin{array}{c}\text { g-value } \\
{[\%]}\end{array}$ \\
\hline Floor slab & $\begin{array}{l}15 \mathrm{~mm} \text { gypsum plaster } \\
+50 \mathrm{~mm} \text { cork }+40 \mathrm{~mm} \\
\text { air gap }+100 \mathrm{~mm} \\
\text { concrete }+20 \mathrm{~mm} \\
\text { cement floor }\end{array}$ & 5.40 & 1.30 & - \\
\hline French door & Double-glazed door & 1.90 & 2.70 & 76 \\
\hline $\begin{array}{l}\text { Partition } \\
\text { wall }\end{array}$ & $\begin{array}{l}20 \mathrm{~mm} \text { cement plaster }+ \\
80 \mathrm{~mm} \text { brick }+180 \mathrm{~mm} \\
\text { cellulose gap filling }+ \\
60 \mathrm{~mm} \text { brick }+15 \mathrm{~mm} \\
\text { gypsum plaster }\end{array}$ & 15.70 & 0.38 & - \\
\hline Windows & $\begin{array}{l}\text { South, single-glazed } \\
\text { West, single-glazed } \\
\text { East, single-glazed }\end{array}$ & $\begin{array}{l}15.70 \\
2.90 \\
2.90\end{array}$ & $\begin{array}{l}5.80 \\
5.80 \\
5.80\end{array}$ & $\begin{array}{l}86 \\
86 \\
86\end{array}$ \\
\hline
\end{tabular}

\subsection{Experimental monitoring}

An experimental monitoring was carried out in the studied apartment from 4th December 2013 to 24th March 2014 (Figure 3). During the monitoring campaign, the apartment was unoccupied and the mechanical heating system turned off, while the sunspace was unventilated and unshaded. The operable air vents in the partition wall were kept open in order to allow the convective heat transfer between the sunspace and the adjacent room. During the monitoring period, the indoor air temperature was recorded in the sunspace and adjacent room (kitchen) with recording thermometers (n. 1 and 2) at 10 minutes time-interval continuously. A third recording thermometer (n. 3) was installed in the West-oriented balcony to record the outdoor air temperature. We used recording thermometers Testo $174 \mathrm{~T}$ with resolution of $0.1^{\circ} \mathrm{C}$ and accuracy of $\pm 0.5^{\circ} \mathrm{C}$ between $-30^{\circ}$ and $+70^{\circ} \mathrm{C}$. Outdoor climate data for the studied location, including outdoor air temperature, humidity and global solar radiation were taken from Savona weather station, which is about two kilometres from the studied building and part of the regional weather station network (OMIRL). Next, we verified possible deviations of outdoor air temperature recorded by Savona weather station from our thermometer n. 3 . Further details on the monitoring are in Refs [41, 42].

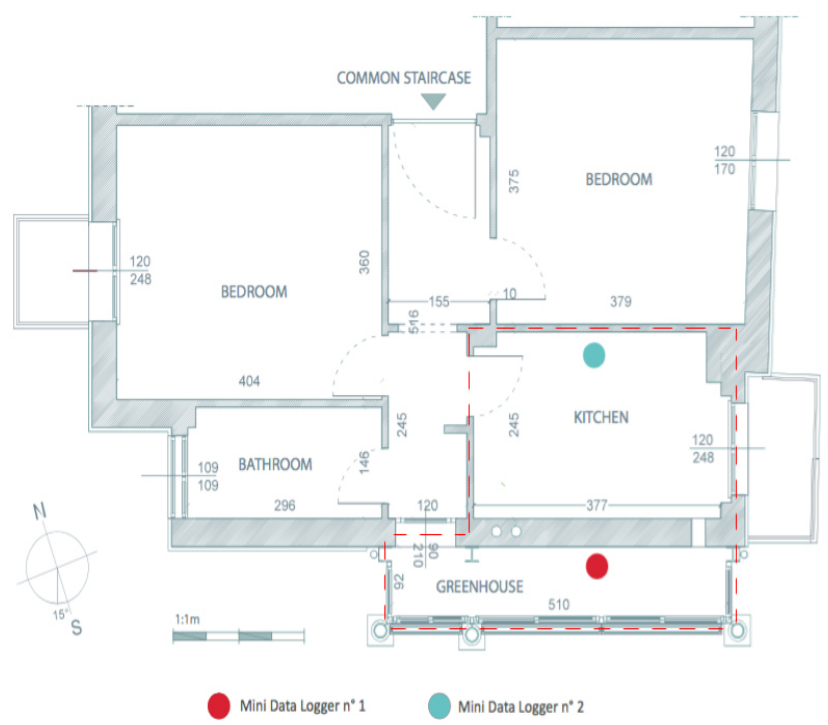

Fig. 3. Plan of the studied apartment with the position of the relevant recording thermometers.

\subsection{Dynamic modelling and simulation}

To validate a dynamic modelling for the sunspace and use it for design optimization, two simulation steps were carried out. First, a simulation model of the sunspace was created and calibrated based on the monitored data Second, different configurations of the sunspace were modelled to optimize the thermal performance based on indoor temperature.

\subsubsection{Reference simulation}

The sunspace and adjacent room were modelled with VIP-Energy software [43]. VIP-Energy software has multi-zone features and performs dynamic and hourly analysis of thermal and energy performance of buildings. The software is validated by the IEA's BESTEST, ANSI/ASHRAE Standard 140 and CEN 15265 as having reliable algorithms and calculation models. The software is increasingly used for building energy simulation 
research, including modelling of highly glazed buildings $[44,45]$. The simulation is based on the input data described in Table 3.

Table 3. Input parameter values and assumptions for the simulation model of the sunspace and adjacent room.

\begin{tabular}{|c|c|c|c|}
\hline Description & Parameter & Input value & Comments \\
\hline \multirow[t]{3}{*}{$\begin{array}{l}\text { Macro- } \\
\text { climate data }\end{array}$} & Temperature & $\begin{array}{l}10.3^{\circ} \mathrm{C} \\
\text { (average); } \\
2.3^{\circ} \mathrm{C} \text { (min.); } \\
19.4^{\circ} \mathrm{C} \text { (max.) }\end{array}$ & $\begin{array}{l}2014 \text { weather data } \\
\text { for Savona } \\
\text { (OMIRL station) }\end{array}$ \\
\hline & $\begin{array}{l}\text { Relative } \\
\text { humidity }\end{array}$ & $\begin{array}{l}63 \% \text { (average); } \\
20 \% \text { (min.); } \\
86 \% \text { (max) }\end{array}$ & $\begin{array}{l}2014 \text { weather data } \\
\text { for Savona } \\
\text { (OMIRL station) }\end{array}$ \\
\hline & $\begin{array}{l}\text { Solar } \\
\text { radiation }\end{array}$ & $\begin{array}{l}116 \mathrm{~W} / \mathrm{m}^{2} \\
\text { (average); } \\
0 \mathrm{~W} / \mathrm{m}^{2} \text { (min.); } \\
503 \mathrm{~W} / \mathrm{m}^{2}(\max )\end{array}$ & $\begin{array}{l}2014 \text { weather data } \\
\text { for Savona } \\
\text { (OMIRL station) }\end{array}$ \\
\hline \multirow[t]{5}{*}{ Heat gains } & $\begin{array}{l}\text { Hot water } \\
\text { circulation }\end{array}$ & $0 \mathrm{~W}$ & $\begin{array}{l}\text { From monitoring } \\
\text { conditions }\end{array}$ \\
\hline & $\begin{array}{l}\text { Lighting } \\
\text { and } \\
\text { appliance }\end{array}$ & $0 \mathrm{~W}$ & $\begin{array}{l}\text { From monitoring } \\
\text { conditions }\end{array}$ \\
\hline & Persons & $0 \mathrm{~W}$ & $\begin{array}{l}\text { From monitoring } \\
\text { conditions }\end{array}$ \\
\hline & $\begin{array}{l}\text { Adjacent } \\
\text { apartment }\end{array}$ & $3.2 \mathrm{~W} / \mathrm{m}^{2}$ & $\begin{array}{l}\text { Calculated based } \\
\text { on [46] }\end{array}$ \\
\hline & Sun & - & $\begin{array}{l}\text { Calculated by VIP } \\
\text { software based on } \\
\text { weather data }\end{array}$ \\
\hline
\end{tabular}

\subsubsection{Design modification and improvements}

We used the simulation model to modify the initial sunspace configuration for optimum indoor thermal performance. The design modifications investigated the depth/volume ratio. Three sunspace configurations were tested, assuming a sunroom depth of $0.45 \mathrm{~m}, 0.60 \mathrm{~m}$ and $1.80 \mathrm{~m}$, corresponding to about $50 \%, 75 \%$ and $200 \%$ of the initial sunspace depth/volume, respectively (Table 4). The sunroom depth of $0.60 \mathrm{~m}$ is the minimum depth to allow the accessibility and maintenance of the sunspace.

Table 4. Characteristics of the initial and improved sunspaces.

\begin{tabular}{lccc}
\hline Sunspace & $\begin{array}{c}\text { Depth } \\
{[\mathrm{m}]}\end{array}$ & $\begin{array}{c}\text { Volume } \\
{\left[\mathrm{m}^{3}\right]}\end{array}$ & $\begin{array}{c}\text { Frame-to-glazing } \\
\text { ratio [\%] }\end{array}$ \\
\hline Initial & 0.90 & 15.0 & 20 \\
Improved: & & & \\
D45 & 0.45 & 7.40 & 20 \\
D60 & 0.60 & 10.0 & 20 \\
D180 & 1.80 & 30.0 & 20 \\
\hline
\end{tabular}

\subsection{Contribution of sunspace for space heating}

The contribution of the sunspace to reduction of the space heating demand of the apartment is calculated as the heat gains entering the adjacent heated room (kitchen) from the sunspace. The direct solar heat gains via the sunspace and indirect heat gains through the partition wall are accounted. We calculate the heat gains through dynamic modelling and also through steadystate method recommended by ISO EN 13790 [19], to compare the outcomes of the alternative approaches. For the dynamic modelling, we use the simulation model of the sunspace previously calibrated and the simulation model of the apartment, comparing the dynamic thermal behaviour with and without sunspace. For the ISO EN 13790 calculation method, we use data of the sunspace, partition wall and glazed window within the sunspace as well as the incident solar radiation for Savona. The average solar absorption factors are taken to be 0.60 and 0.12 for the opaque and glazed building elements, respectively, based on Asdrubali et al. [20]. The sunspace adjustment factor $\left(b_{t r}\right)$ is assumed to be 0.40 , based on UNI/TS 11300-1 [47]. A shading factor of 1.0 is used in the calculations as no shading device is applied on the sunspace and there is no obstruction of the direct solar radiation to it.

\section{Results}

\subsection{Experimental monitoring of the sunspace}

The monitored air temperature values show a consistent trend between outdoor, sunspace and adjacent room. The maximum/minimum/average air temperatures for outdoor, sunspace and adjacent room, respectively, are 17.6/3.3/11.1, 52.0/8.6/19.1 and 19.8/14.3/17.3 ${ }^{\circ} \mathrm{C}$ in December, $\quad 17.0 / 2.0 / 9.2, \quad 50.8 / 7.1 / 14.8 \quad$ and 18.2/13.7/15.9 ${ }^{\circ} \mathrm{C}$ in January, 17.9/3.0/10.1, 48.2/7.9/16.4 ${ }^{\circ} \mathrm{C}$ in February, and finally 21.5/2.8/13.2, 40.6/8.1/20.2 and 22.4/13.3/18.5 ${ }^{\circ} \mathrm{C}$ in March. Figure 4 shows the temperature values in January. The sunspace air temperature significantly depends on the outdoor temperature, as well as on the solar radiation. The maximum/average solar radiation is $454 / 59 \mathrm{~W} / \mathrm{m}^{2}$ in December, $503 / 44 \mathrm{~W} / \mathrm{m}^{2}$ in January, $632 / 85 \mathrm{~W} / \mathrm{m}^{2}$ in February, and 827/142 W/m² in March.

The outdoor temperature can affect the efficiency of the attached sunspace as a passive heating system, as well as the apartment heating demand. To analyse the thermal behaviour of the sunspace, we select the month of January, when the lowest maximum, minimum and average outdoor temperatures are recorded. Besides, a significant average solar radiation $\left(>100 \mathrm{~W} / \mathrm{m}^{2}\right)$ is recorded on the $15^{\text {th }}, 25^{\text {th }}, 26^{\text {th }}$ and $28^{\text {th }}$ of the same month. We select the day of $15^{\text {th }}$ January based on three parameters: average outdoor air temperature, maximum sunspace air temperature, and temperature increase in the adjacent room during the assumed heating time. On $15^{\text {th }}$ January, the maximum/minimum/average temperatures for outdoor, sunspace and adjacent room, respectively, are $14.9 / 5.8 / 9.5,47.1 / 8.5 / 19.5$ and $16.6 / 14.8 / 15.6{ }^{\circ} \mathrm{C}$. 


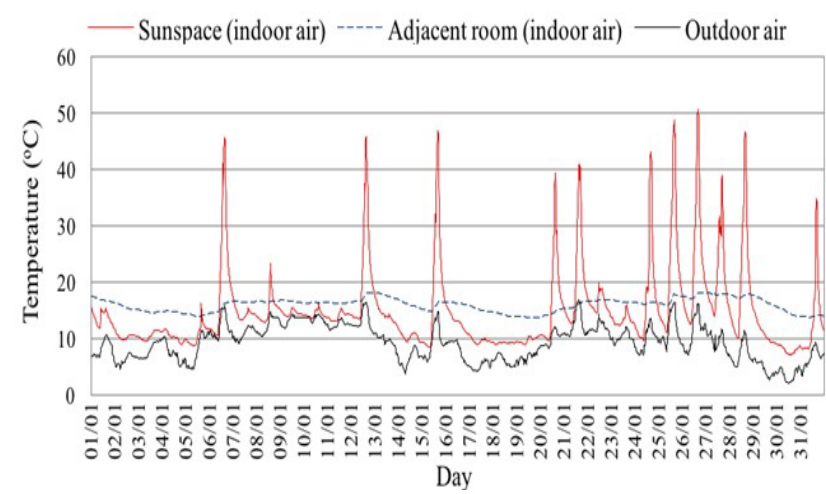

Fig. 4. Outdoor and indoor air temperature during the monitoring campaign (from $1^{\text {st }}$ to $31^{\text {st }}$ January).

\subsection{Dynamic simulation of the sunspace}

We run a dynamic simulation of the sunspace on $15^{\text {th }}$ January, and compare the results with the data recorded during the monitoring campaign in the same day. Besides, we design alternative configurations of the sunspace with different values of depth and volume, in order to increase the indoor air temperature of the sunspace and optimize the thermal behaviour (Figure 5).

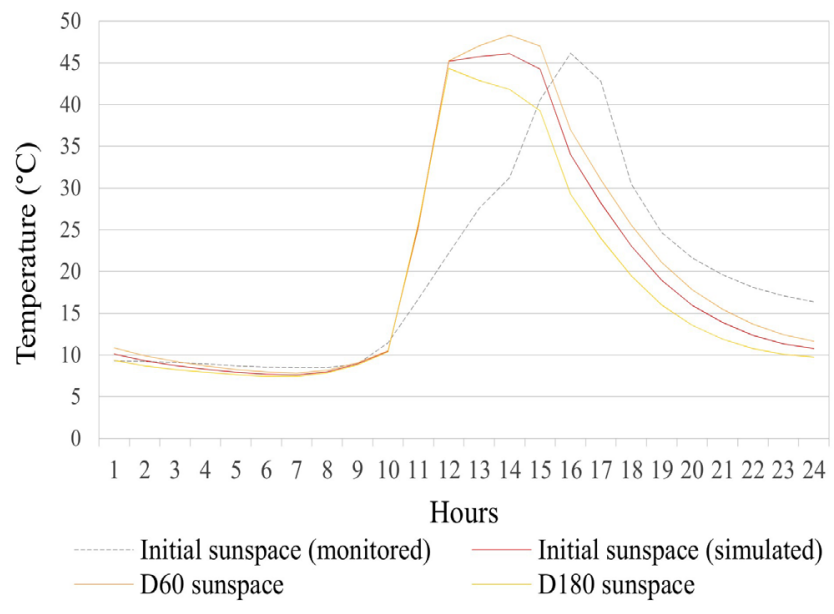

Fig. 5. Simulated and monitored air temperature $\left({ }^{\circ} \mathrm{C}\right)$ of the initial sunspace, and simulated air temperature of the half-size (D60) and double-size (D180) sunspaces, on $15^{\text {st }}$ January.

Table 5 shows the maximum, minimum and average indoor air temperatures of the monitored and simulated initial sunspace, as well as the simulated half-size (D60) and double-size (D180) sunspaces. The maximum, minimum and average temperatures of the simulated initial sunspace are $0.1 \%, 10 \%$ and $0.5 \%$ lower compared to the monitored sunspace.

Table 5. Air temperature of initial, D60 and D180 sunspaces.

\begin{tabular}{lccc}
\hline Description & $\begin{array}{c}\text { Max } \\
{\left[{ }^{\circ} \mathrm{C}\right]}\end{array}$ & $\begin{array}{c}\text { Min } \\
{\left[{ }^{\circ} \mathrm{C}\right]}\end{array}$ & $\begin{array}{c}\text { Average } \\
{\left[{ }^{\circ} \mathrm{C}\right]}\end{array}$ \\
\hline $\begin{array}{l}\text { Initial sunspace: } \\
\text { Monitored }\end{array}$ & 46.2 & 8.5 & 19.4 \\
$\quad$ Simulated & 46.1 & 7.6 & 19.3 \\
Improved sunspace: & & & \\
D60 - simulated & 48.3 & 7.8 & 20.4 \\
D180 - simulated & 44.3 & 7.4 & 17.6 \\
\hline
\end{tabular}

We observe a time offset between the simulated and monitored air temperature from 10.00 a.m. onwards. The time offset increases to about 2 hours at 2.00 p.m., when the maximum air temperature is reached by the simulated sunspace, and decreases to 1.5 hours onwards. The maximum, minimum and average air temperature of the D60 sunspace are 5\%,3\% and 6\% higher compared to the simulated initial sunspace, while the same values of the D180 sunspace are 4\%,3\% and 9\% lower.

\subsection{Contribution of sunspace to space heating}

Figure 6 shows the influence of the initial sunspace, calculated through dynamic modelling (VIP) and steadystate method (ISO), for each day of January. It demonstrates that the overall heat gains calculated through dynamic modelling have an average deviation of $-55 \%$ from those calculated through steady-state method, and average deviation of $+36 \%$ from the indirect gains calculated through the steady-state method. This is because the applied dynamic modelling tool calculates only indirect heat gains from the sunspace, and it is unable to calculate the direct heat gains through a double envelope (e.g. the transparent and opaque surfaces of the sunspace and partition wall, respectively). Combining the indirect heat gains from dynamic modelling and the direct heat gains calculated based on [19], we find that the values of overall heat gains have an average deviation of $+39 \%$ from those based on the steady-state method. The contribution of the sunspace to space heating of the apartment was 6.8 and $6.9 \mathrm{kWh}$ on the peak day in January, based on the steady-state and combined methods, respectively. Figure 7 shows the influence of the initial sunspace for each month during the monitoring period from January to March. On monthly average basis, the contributions of the sunspace to the space heating of the apartment ranged from 2.2 and $2.5 \mathrm{kWh} /$ day during January to 6.80 and 7.2 $\mathrm{kWh} /$ day during March, using the steady-state and combined method, respectively. The overall average contribution of the sunspace for this period is 4.0 and $4.35 \mathrm{kWh} / \mathrm{day}$, based on steady-state and combined method, respectively.

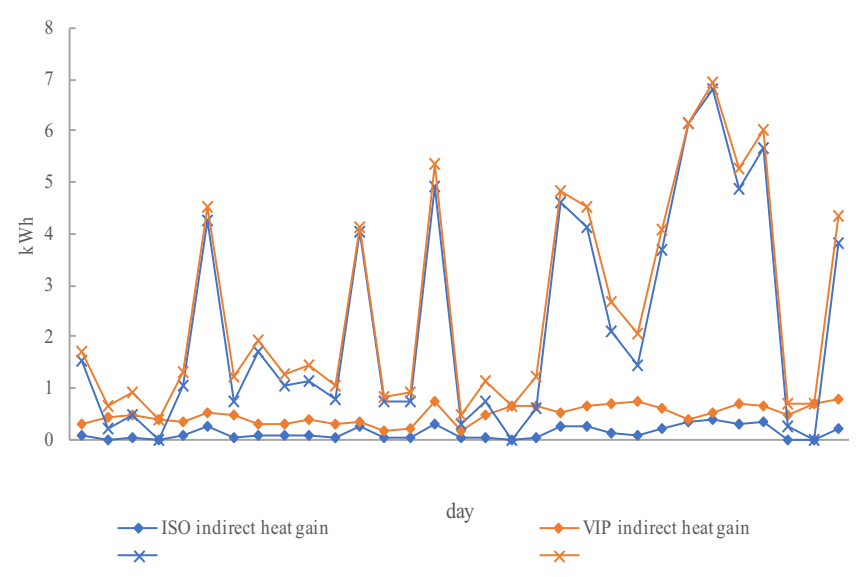

Fig. 6. Contribution of the sunspace to daily space heating for the month of January . 


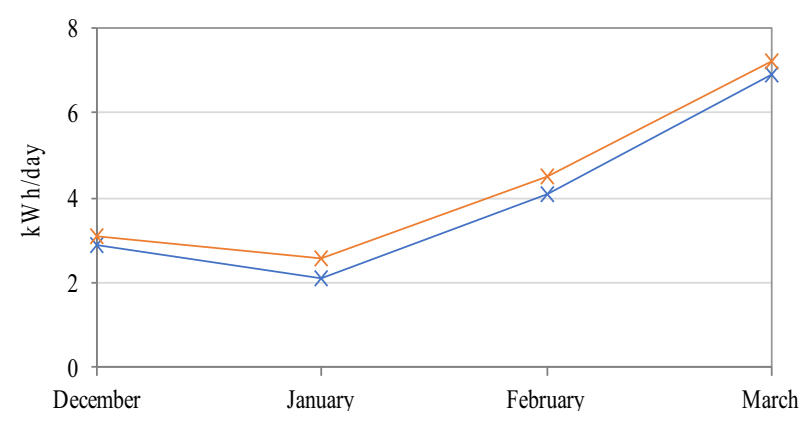

Fig. 7. Monthly average heating contribution of the sunspace

\section{Discussion and conclusions}

This study integrated experimental field monitoring and detailed simulation as well as modelling to analyse the thermal behaviour of an attached sunspace in an existing Italian building, and demonstrated the contribution of this passive solar heating system to the building's thermal performance and energy efficiency. Overall, the results indicate that the sunspace can contribute significantly to the space heating of the adjacent room and apartment. With plausible design modifications of the sunspace, indoor air temperature and hence solar energy gains are significantly increased, in contrast to the existing configuration.

The maximum and average air temperatures of the simulated and monitored initial sunspace are consistent. A significant time offset between the simulated and monitored sunspace is observed in the daily temperature trend, especially during the heating time, between 10.00 a.m. and 2.00 p.m. This can be due to approximations in the heat transfer modelling, including the calculation of convective heat transfer between the sunspace and the adjacent room occurring by the existing air vents. Although the experimental monitoring showed a negligible contribution of convective heat transfer through the air vents [42], the simulation model may be further calibrated.

The design modifications of the sunspace volume show that the depth of the sunroom, and consequently its glazing area and the overall volume, affect the indoor temperature significantly. Decreasing the depth and volume of the initial sunspace by $50 \%$ increases the maximum and average temperature by 5 and $3 \%$, respectively. Besides, increasing the depth and volume of the initial sunspace by $200 \%$ decreases the maximum and average temperature by 4 and $3 \%$. This is due to the increase of the glazing area within the sunspace, as well as the average $\mathrm{U}$-value, resulting in higher heat losses.

The increase of the air temperature in the attached sunspace improves its thermal performance and contributed to the apartment's overall energy balance as energy savings benefit. The calculated energy inputs from the initial sunspace to the adjacent apartment ranged between 2.2-6.80 and 2.5-7.2 $\mathrm{kWh} /$ day from January and March, when calculating the indirect heat gains from the sunspace through steady-state method and dynamic modelling, respectively. The overall heat gains calculated by combining steady-state and dynamic methods are $11 \%$ higher, on average, compared to the simple steady state. This is consistent with the findings of Asdrubali et al. [20], who showed that the steady-state method proposed by ISO EN 13790 [19] underestimates the heat gains compared to dynamic simulation. The daily average contribution of the sunspace to the space heating of the apartment comes to 4.0 and $4.35 \mathrm{kWh}$ for the analysed period when using steady-state and combined calculation methods, respectively. This contribution translates to about $10 \%$ reduction of the space heating requirement of the apartment, which was projected to have a space heating demand of 140 $\mathrm{kWh} / \mathrm{m}^{2}$. Design modifications of the sunspace resulted in increased air temperature and this will further enhance the space heating saving benefits. These modifications can serve as basis for optimal design and configuration of sunspaces for improved energy and thermal performance.

The on-site monitoring campaign was supported by the Regional Housing Department of Savona. The simulation activities were possible thanks to the research collaboration between the Department of Architecture and Design of the University of Genova (Italy) and the Department of Built Environment and Energy Technology, and Department of Building Technology, of Linnaeus University (Sweden).

\section{References}

1. IPCC, Climate Change 2014: Mitigation of Climate Change. Contribution of Working Group III to the Fifth Assessment Report of the Intergovernmental Panel on Climate Change (2014)

2. EEA, Primary energy consumption by fuel. Accessed at https://www.eea.europa.eu/data-andmaps/indicators/primary-energy-consumption-byfuel-6/assessment-2 on 15 January 2020

3. IEA, World Energy outlook 2016 (2016). Accessed at https://www.iea.org/newsroom/news/ 2016/november/ on 15 January 2020

4. N. H. Stern, S. Peters, V. Bakhshi, A. Bowen, C. Cameron, S. Catovsky, D. Crane, S. Cruickshank, S. Dietz, N. Edmonson, S.-L. Garbett, L. Hamid, G. Hoffman, D. Ingram, B. Jones, N. Patmore, H. Radcliffe, R. Sathiyarajah, M. Stock, C. Taylor, T. Vernon, H. Wanjie, and D. Zenghelis, Stern Review: The Economics of Climate Change (CUP, Cambridge, 2006)

5. UNFCCC, Paris agreement (2015). Accessed at https://unfccc.int/process-and-meetings on 15 January 2020

6. Ministry of Economic Development, Italy's national energy strategy: For a more competitive and sustainable energy (2013). Accessed at https://www.mise.gov.it/images/stories/document i/SEN_EN_marzo2013.pdf on 15 January 2020

7. Ministry of Economic Development, National energy strategy 2017 (2017). Accessed at https://www.mise.gov.it/images/stories/document 
i/Testo-integrale-SEN-2017.pdf on 15 January 2020

8. Directive 2010/31/EU of the European Parliament and of the Council of 19 May 2010 on the energy performance of buildings (Official Journal of the European Union, L 153, 2010)

9. G. Iorio, A. Federici, Energy efficiency trends and policies in Italy (2018). Accessed at http://www.odyssee-ure.eu/publications/nationalreports/energy-efficiency-italy.pdf on 29/11/2018 on 15 January 2020

10. Y. Saheb, K. Bódis, S. Szabó, H. Ossenbrink, S. Panev, Energy Renovation: The Trump Card for the New Start for Europe (Publications Office of the European Union, Luxemburg, 2015)

11. Law n. 90 of 3 August 2013 (in Italian) (G.U. n. 181 of 3 August 2013)

12. Ministry of Economic Development (Italy), InterMinisterial Decree 26 June 2015. Adaptation of national guidelines for energy certification of buildings (2018). Accessed at https://www.gazzettaufficiale.it/ on 15 January 2020

13. C. Cristofari, R. Norvaišienè, G. Notton, Legal issues, in: S.A. Kalogirou (Ed.), Building Integrated Solar Thermal Systems, Design and Applications Handbook - COST Action TU1205 BISTS, 229-248 (2017)

14. H.-Y. Chan, S.B. Riffat, J. Zhu, Renew. Sust. Energy Rev. 14 (2) 781-789 (2010)

15. D. Harvey, Energy and the new reality 1 - Energy efficiency and the demand for energy services (Earthscan, London, 2010)

16. G. Mihalakakou, Renew. Energy 26 415-429 (2002)

17. G. Chiesa, M. Simonetti, G. Ballada, Energy Build. 138 377-395 (2017)

18. EN ISO 13789:2017. Thermal performance of buildings - Transmission and ventilation heat transfer coefficients - Calculation method

19. EN ISO 13790:2017. Energy performance of buildings - Calculation of energy use for space heating and cooling

20. F. Asdrubali, F. Cotana, A. Messineo, Energies, 5(6) 1864-1880 (2012)

21. M.O. Panão, S.M.L. Camelo, H.J.P. Gonçalves, Energy Build. 51 212-222 (2012)

22. A. Buonomano, G. De Luca, U. Montanaro, A. Palombo, Energy Build. 121 318-343 (2016)

23. Á. Ruiz-Pardo, S.A. Domínguez, J.A.S. Fernández, Energy Build. 42 (6) 763-773 (2010)

24. K. M. Bataineh, N. Fayez, Energy Build. 43 (8) 1863-1868 (2011)

25. D. Aelenei, H. de Azevedo Leal, L. Aelenei, Energy Procedia 48 1436-1441 (2014)

26. S. Stevanović, Renew. Sust. Energy Rev. 25 177196 (2013)
27. M. Santamouris, E. Dascalaki, Build. Environ. 37 (6) 575-578 (2002)

28. G. Oliveti, N. Arcuri, M. De Simone, R. Bruno, Renew. Energy 39 (1) 241-249 (2012)

29. D. Ignjatović, M.J. Popović, J. Kavran, Energy Build. 98 3-9 (2015)

30. S.S. Chandel, R.K. Aggarwal, Renew. Energy 33 2166-2173 (2008)

31. M. Chen, Y. Shi, TCSAE 27 (11) 232-235 (2011)

32. E. Krüger, B. Givoni, Build. Environ. 431792 1804 (2008)

33. J. Zhu, B. Chen, Energy Build. 67 445-452 (2013)

34. A.R. Rempel, A.W. Rempel, K.V. Cashman, K.N. Gates, C.J. Page, B. Shaw, Build. Environ. 60 158-172 (2013)

35. J.-M. Mottard, A. Fissore, Solar Energy 81 (3) 305-315 (2007)

36. A. Sánchez-Ostiz, A. Monge-Barrio, S. DomingoIrigoyen, P. González-Martínez, Energy Build. 80 231-246 (2014)

37. M. Owrak, M. Aminy, M.T. Jamal-Abad, M. Dehghan, Build. Environ. 92 142-151 (2015)

38. G. Ulpiani, D. Giuliani, A. Romagnoli, C. Di Perna, Energy Build. 152 194-215 (2017)

39. A. Monge-Barrio, A. Sánchez-Ostiz, Energy Build. 108 244-256 (2015)

40. OMIRL, Meteoclimatic data - Savona weather station. Accessed at http://www.cartografiarl.regione.liguria.it/SiraQu alMeteo/Fruizione.asp on 10 January 2020 (2018)

41. A. Giachetta, C. Piccardo, A. Magliocco, Monitoring of Passive Solar Systems in Retrofitted Buildings, in: Advanced Building Skins - Conference Proceedings of the 9th Energy Forum, 909-923 (2014)

42. A. Giachetta, A. Magliocco, C. Piccardo, Performance of Passive Solar Systems in a Case of Retrofitted Buildings, in: S. Alifragkis, N. Patricios (Eds.), Architecture Anthology II: Architectural Technology, 17-37 (2016)

43. StruSoft. VIP-Energy software, Version 4.2.3 (2019)

44. I. Danielski, G. Nair, A. Joelsson, M. Fröling, Build. Environ. 106 352-364 (2016)

45. A. Dodoo, L. Gustavsson, Energy 97 534-548 (2016)

46. T.-A. Kõiv, A. Hamburg, M. Thalfeldt, J. Fadejev, Indoor climate of an unheated apartment and its impact on the heat consumption of adjacent apartments, in: M. Zahran (Ed.), Latest trends in sustainable and green development, 52-57 (2012).

47. UNI/TS 11300-1. Energy Performance of Buildings (2014) 